\title{
知識グラフに基づく質問応答機能を備えた三者対 話チュータリングシステムの開発
}

\section{Development of Interactive Tutoring System with Question Answering Function based on Knowledge Graph}

\author{
小嶋 拓海 \\ 京都工芸繊維大学 大学院工芸科学研究科 情報工学専攻 \\ Takumi Kojima \\ Graduate School of Information Science and Technology, Kyoto Institute of Technology \\ kojimalii.is.kit.ac.jp \\ $\underset{\text { T飯田 环矢 }}{\text { Takua IIDA }}$ \\ 京都工芸繊維大学 工芸科学部 情報工学課程 \\ Department of Information Science and Technology, Kyoto Institute of Technology \\ iidaeii.is.kit.ac.jp \\ 寺西帝乃
Daina TERANISHI \\ (同上) \\ teranishi@ii.is.kit.ac.jp \\ 荒木 雅弘 \\ 京都工芸䋊維大学 大学院工芸科学研究科 情報工学専攻 \\ Graduate School of Information Science and Technology, Kyoto Institute of Technology \\ araki@kit.ac.jp
}

keywords: tutoring system, dialogue system, knowledge graph, question answering

\section{Summary}

Interactive tutoring systems is expected to contribute self-learning in various type of topics, such as machine learning. In this study, we develop an interactive tutoring system that performs tutoring in a three-party dialogue form using multiple virtual agents. It would reduce the psychological burden of the learner compared with one-to-one tense dialogue. To adapt this system to various levels of users, question-answering functionality is essential. The proposed system generates an answer to the question using a knowledge graph automatically constructed from the textbook.

\section{1. は じめに}

ある分野の初学者が対象分野の内容を独学により習得 する方法として，国内外の多くの大学で公開されている オンライン講座を活用することが考えられる．これらの 講座は講義ビデオに加えて講義で使用されたスライドや 演習課題も含めて公開されている場合もあり, 学習者の 事前知識と講義で提供される内容のレベルが一致すれば, 極めて有用なリソースであるといえる.

一方で事前知識のレベルが異なる多様な初学者に対応 した複数の教材を提供することは難しい. 学習者のレベ ルに合わせた動的な配信コンテンツの制御や質問応答機 能が提供できる知的チュータリングシステムは，オンラ イン講座をサポートするリソースとして有用性が高いと 考えられる。

ユーザに適応可能なチュータリングシステムを実装す るためには, ユーザの発言から理解度を推定することが 自然であるので, 擬人化エージェントとの対話システム は実装の選択肢となる.しかし, 教師役のエージェント と学習者が一対一で対話を行う方式では, 説明や質問を 行う対象が学習者一人に集中し学習者の心理的負担が大
きくなるという問題がある.

そこで本研究では, 学習者の心理的負担を軽減しつつ, 適度な緊張感を持って学習を続けることができる形態と して三者対話によるチュータリングシステムの実装を行っ た. Sakamoto ら [Sakamoto 09] は，対話ロボットを受動 的かつ社会的な放送媒体として用いるために，杉山ら[杉 山 17] は, 雑談対話における対話破綻を軽減し対話を維 持するために, 有本ら [有本 18] は, 実環境での実験で三 者対話による対話感向上を検証するために研究を行って いる.それらの結果から, 複数対話ロボットを用いる三 者対話では, 二者対話よりも魅力感, 対話感を与え, 対 話破綻感を軽減するという結果が得られている．本研究 では, 教師エージェントと生徒エージェントの 2 体の擬 人化エージェントを用い，教師役が生徒役に説明・質問 を行って教えてゆくという過程の中で, 時折学習者に働 きかけを行うという形態をとる。このことで，学習者へ の心理的負担を軽減し, 適度なアウトプットを行わせる ことで学習者に適度な緊張感を持たせることができる.

また，チュータリングシステムにおいては，一方的に 知識を伝えるだけではなく，学習者の質問に回答する機 能が必要となる。しかし，チュータリングのようなタス 


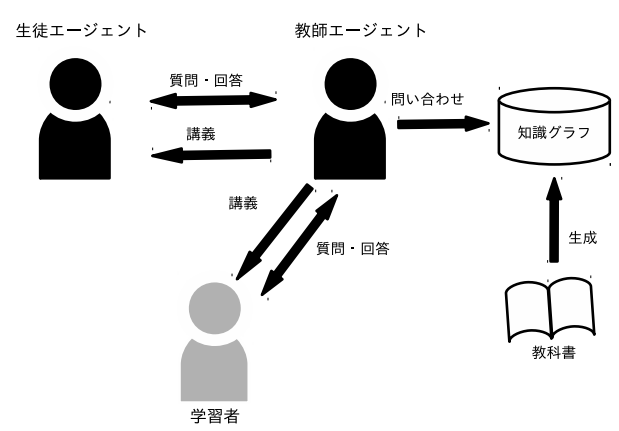

図 1 三者対話チュータリングシステム

クでは機械学習によって回答を検索，生成できる程度の 大規模な質問応答対を入手・作成することが困難である. 本研究では回答を用意するための知識構築コストの面か ら，教科書から単語間の関係を捉えた知識グラフを生成 し，それに問い合わせて得られた結果を用いて学習者か らの質問に対する回答を生成した。

以上の方法を用いて，三者対話チュータリングシステ ムを開発した。対象科目としては著者のうち 1 名が著述 した教科書が利用できる機械学習分野を選択した。シス テムの位置づけを図 1 に示す. 本研究でのチュータリン グにおける応答生成は, 教科書から知識グラフを生成し 問い合わせに利用する手法であり，大規模なデータセッ トがない状況で適用可能となると考えられる.

\section{2. 関 連 研 究}

関連研究として三者対話システムに関する研究及び, 知識グラフに関する研究を挙げる.

\section{$2 \cdot 1$ 三者対話システム}

現在実用化されている対話システムの多くは二者対話 型のものであるが，擬人化エージェントやロボットを対 話相手とする研究においては，三者あるいはそれ以上の 対話参加者を前提とするものもいくつかある.

Swartout ら [Swartout 10] は，博物館の来訪者へのガ イドを行う 2 体のエージェントによる対話システムを実 装している。 久保田ら [久保田 02] は，会話形式に変換 したニュースの情報を三者対話形式で提供することによ り，二者対話と三者対話での比較実験から特に長い文章 を提供する場合に三者対話がユーザの理解を促進するこ とを示している. また，Sakamoto ら [Sakamoto 09] は， 対話ロボットを受動的かつ社会的媒体として利用するこ とを提案しており，放送媒体として駅で用いるフィール ド実験を行った。実験結果から，一方的に情報提供を行 う二者対話より対話ロボット間での会話が行われる三者 対話のほうが情報提供時に人々の関心を集め，対話感を 与えることを示している。これらから，三者対話はユー
ザへの情報提供に関して二者対話より理解や魅力の点で 優れているといえる.

Yoshikawa ら [Yoshikawa 17] は，対話感向上のために 人間 1 人と複数の対話ロボットからなる小規模な対話に 影響を与える対話パターンを分析している. 3 つの対話 パターンに制限した二者対話と三者対話での比較実験に より三者対話が会話継続やロボットへの印象，一貫性な どで高評価を得たことを示している．また，杉山ら [杉 山 18] は，対話破綻回避を目的に三者対話を用いた研究 を行い，ユーザ発話に対する対話ロボットの発話が破綻 を起こしていた際，即座に対話ロボット間で不確定要素 のない成立する応答対を発話することで全体の破綻を回 避させることを提案している. 二者対話との比較実験に より，三者対話では満足感や破綻感が改善されたことを 示している. 有本ら [有本 18] は，対話破綻や対話参加 欲求の低いユーザの存在を仮定し，そのような状況でも ユーザの対話感を高めるようなシステム構成を提案して いる．有本らはロボット間の予定調和的な応答による対 話破綻回避やロボット間の対話提示を行うことで対話感 が向上し，対話が維持されると考え，実環境での実験に より高度な音声認識を行うことなく情報提示し，対話の 場を維持できることを示唆している.

これらの研究で，三者対話においてロボット間での対 話による情報提示によりユーザの対話感は失われにくい ことが示されてもいることから, 本研究では教師エージェ ントが学習者のみではなく生徒エージェントへも質問を 行う対話形式を採用した。

Graesser ら [Graesser 17] は三者対話形式でチュータ リングシステムを構築し、様々な役割設定や対話パター ンの組合せに対して、適した学習者特性を検討している. それらは短い学習課題で検討され、本研究の対象である 機械学習のような一定期間の継続的学習が必要なテーマ に関して、三者対話のどのような機能が効果的であるの かは検討されていない。本研究では、三者対話形式がシ ステムの長期的な利用につながるという観点から、学習 者の心理的負担の軽減という機能に着目した。

\section{$\mathbf{2} \cdot \mathbf{2}$ 知 識 グラ フ}

チュータリングシステムにおいて，ユーザからの質問 に対して回答を生成する際に用いる知識表現は，その妥 当性の検証が容易であることが望ましい，知識グラフに よる知識表現は，そのような要求を満たすもののひとつ である。

対象とするドメインのテキストを利用して知識グラフ 生成を行う研究がある. Luan ら [Luan 18] は, 英語の AI 関連論文のアブストラクトから知識を抽出する手法を提 案し, SCIERC というデータセットを作成している。本 研究では, チュータリングというタスクに合わせ教科書 から知識グラフの生成を行った.

作成された知識グラフは往々にして完全ではなく，未 
知のエンティティや欠落情報が存在する. 既存の知識グラ フヘのマッピングに関する研究として, Kertkeidkachorn ら [Kertkeidkachorn 18] は，自然言語テキストから自動 で知識グラフを生成するフレームワーク $\mathrm{T} 2 \mathrm{KG}$ を提案し, DBpedia へ新しい情報のマッピングを行っている.

知識グラフは多くの研究で質問応答タスクに用いられ ており, Bordes ら [Bordes 14] は, FREEBASE を知識 ベースとして部分グラフ埋め込みを用いた応答手法を情 報検索と意味解析を軸に提案している.この手法では, 質問とその回答が結合埋め込み空間内で近くに表せるよ うに，単語低次元ベクトル埋め込みと FREEBASE の関 係タイプを学習する. 推論時に, 質問から知識グラフ内 のエンティティを含むすべてのトリプルを候補セットに するより, 関係タイプの上位 10 タイプがパスに現れる 2 ホップ候補のみを候補セットにするほうが優れているこ とを示している.

\section{3. 三者対話によるチュータリングシステム}

チュータリングシステムにおいて実現するべきことと して, (1) スマートフォン, タブレット, PC で動作する マルチデバイス化，(2) 低い開発コスト，(3) 多様な知識 レベルのユーザへの対応を設定する.

そして本研究では, 学習者の興味を惹きつけたうえで 心理的負担を減らすために三者対話方式を採用する。し かし, 三者対話形式はシナリオ記述が煩雑になり, 事前 知識の異なる様々なレベルの学習者に向けての複数のシ ナリオの実装は難しい. そこで質問応答機能を付加する ことで，多様な学習者へ対応することとした。

本チュータリングシステムでは, PocketMMDAgent *1 上で教師エージェントと生徒エージェント，学習者の三 者による音声対話形式でスライド資料を用いたチュータ リングを行い，学習者からの質問受付時に web ブラウザ 上で質問に対して音声による回答提示を行う。チュータ リング画面の例を図 2 に, 質問応答ページを図 3 に示す.

PocketMMDAgent とは, キャラクタエージェントとの 音声対話を自在に構築できるマルチデバイス対応のプラッ トフォームであり, 同じく音声対話システムを構築する オープンソースツールキットである MMDAgent [李 11] 用の音声対話コンテンツを web からダウンロードし再生 することができる.

\section{$3 \cdot 1$ システムの構成}

本チュータリングシステムは図 4 のように構成し, サー バ側とクライアント側に大別できる.サーバ側はコンテ ンツサーバ, web サーバ, API サーバ, SPARQL サーバ, ログサーバを，クライアント側では PocketMMDAgent, web ブラウザを構成要素とする. システムで利用する データや質問応答機能をサーバに持たせることで学習者

\footnotetext{
*1 PocketMMDAgent: https ://mmdagent.lee-lab.org/
}

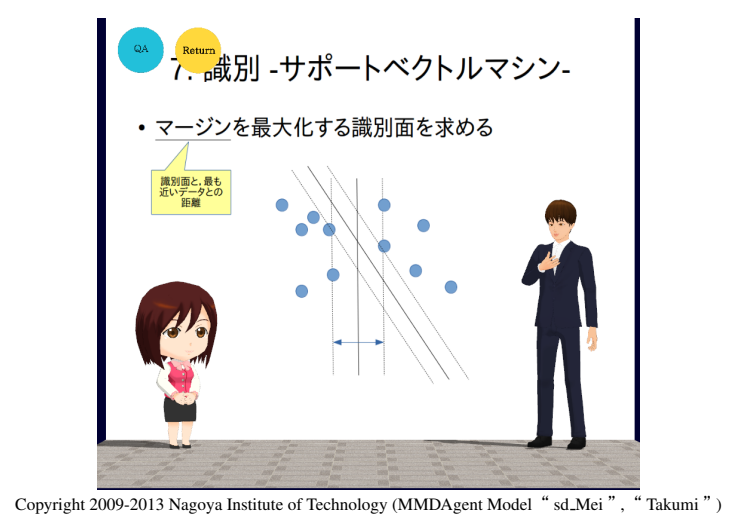

図 2 PocketMMDAgent による三者対話チュータリングの画面

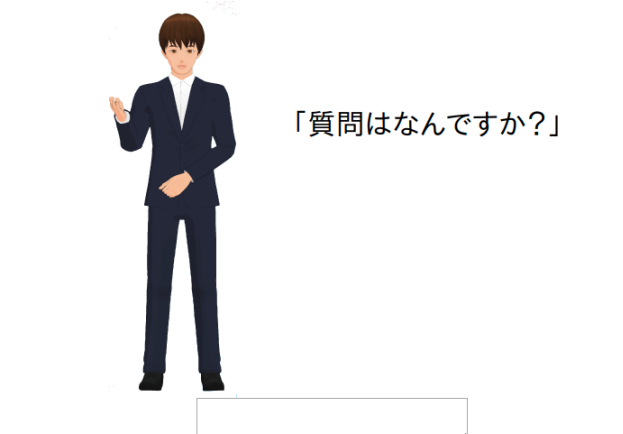

図 3 質問応答ページ画面

は PocketMMDAgent と web ブラウザを用意するだけで， システムを利用することが可能になる．シナリオの更新 やログ収集などはサーバ側で行う.

PocketMMDAgent は, コンテンツサーバからチュータ リング用コンテンツのダウンロード並びにシナリオ再生, 質問応答ページオープンのためのリクエスト，ログサー バへのログ送信を行う. PocketMMDAgent ではシステム の発話内容及びユーザの発話パターンはシナリオに記述 されている必要があるが, 学習者からの質問は不定であ るため, 予めその発話パターンを記述しておくことは不 可能である，そのため，学習者からの質問に答える機能 は PocketMMDAgent 上では実現が難しい，そこで，本 研究では別途 web ブラウザを用いることで質問応答機能 の実装を行う。web ブラウザは PocketMMDAgent から のリクエストによるレスポンスとして質問応答ページを 表示し，学習者からの質問を受け取りサーバ側で生成さ れた回答を再生することで質問応答対話を行う.

web サーバと API サーバからなる web アプリケーショ ンサーバは質問応答を行うためのサーバである. web サー バでは質問音声を認識及びテキスト化し，API サーバで は回答文とその音声ファイルを生成する．回答生成を行 う際，SPARQL サーバへのクエリ送信により知識グラ フヘの問い合わせを行い知識グラフ上のデータを取得す る. web ブラウザの音声認識インタフェースには webkit- 


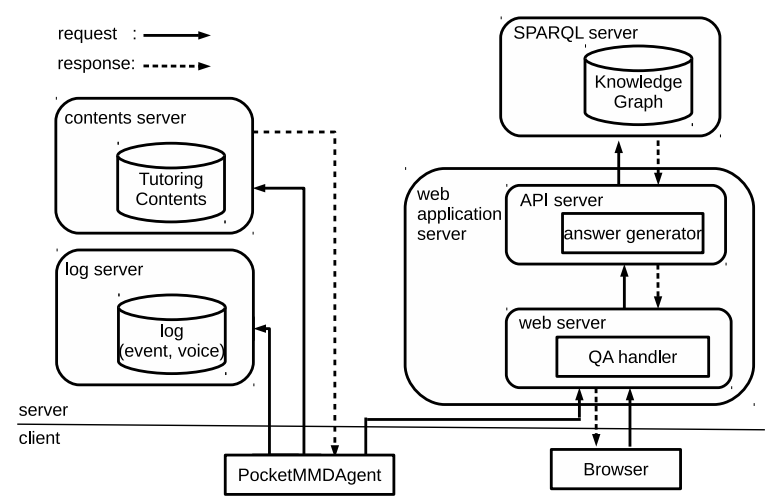

図 4 チュータリングシステムの構成

SpeechRecognition を, 音声ファイル再生には webkitAudioContextを用いた。

また，PocketMMDAgent では対話時のユーザ音声を ファイル化したものと動作ログテキストをログサーバに 送信することができる。この機能を利用して，本チュー タリングシステムでは学習者の学習履歴を収集すること が可能となる. PocketMMDAgent では対話コンテンツの 動的更新も可能であり，コンテンツサーバ上でシナリオ などを更新した際，PocketMMDAgent の再起動とともに 更新を随時反映することができる.

\section{$3 \cdot 2$ 対話シナリオの構成}

PocketMMDAgent の対話シナリオは状態遷移を制御す る FST コマンドからなる FST ファイルによって記述され る．FST コマンドでは，エージェントの追加削除，動作 の追加削除, 背景画像の変更, 音声認識, 音声合成, 変 数操作, タイマー機能などが記述可能である. 本研究で は，チュータリングシステムのための対話シナリオ要素と して (1) 教師エージェントによる講義発話，(2) 教師エー ジェントと生徒エージェント間の対話・質問応答，(3) 教 師エージェントから学習者への質問, (4) 教師エージェン トから学習者への応答, (5) 章の選択, (6) スライドの変 更を設定する。

このような三者対話構成とすることで，人が聞き役と なる状況，すなわちエージェント間で対話が行われる状況 でも聞き役に対話感を与えることができ [Yoshikawa 17], エージェント間で対話を行うことで学習者の対話感を損 なわず心理的負担を軽減できると考えられる．要素 (1), (2) では，教師エージェントは講義内容の説明や生徒エー ジェントへの質問・問いを行い，生徒エージェントは予 め記述された発話を返す。また，講義中に表示するスラ イド資料は背景画像を変更することで容易に切り替える ことができる．要素 (3) では，教師エージェントの質問に 対する学習者の回答を待ち, その後教師エージェントに よる正解と解説の発話を行う。これにより学習者にアウ
表 1 シナリオテキスト例

SLIDE_[slide_path]
LEC
teach:SVM はパターン認識モデルです。

表 2 FST ファイル例

89 <eps $>$ STAGE| [ floor_path ], [ slide_path ] $910<$ eps $>$ ROTATE_START $\mid$ teach $|0.0,-30.0,0.0|$ GLOBAL $\mid 50.0$ $1011<$ eps $>$ ROTATE_START $\mid$ stu $|0.0,30.0,0.0|$ GLOBAL $\mid 50.0$ 1112 ROTATE_EVENT_STOP $\mid$ stu $<$ eps $>$ $1213<$ eps > MOTION_ADD|teach|teach_talk| [motion_path] $\mid$ FULL $\mid$ LOOP $\mid$ ON $\mid$ OFF

1314 <eps > SYNTH_START|teach|takumi_voice_normal| SVM はパターン認識モデルです

1415 SYNTH_EVENT_STOP|teach TIMER_START|between|1 1516 TIMER_EVENT_STOP|between <eps>

$1617<$ eps $>$ MOTION_DELETE|teach|teach_talk

1718 MOTION_EVENT_DELETE|teach|teach_talk <eps $>$

トプットを促し，正しい知識を与えることができると考 えられる. 要素 (4) では, シナリオを一時中断し学習者 からの質問に対して web ブラウザ上の質問応答ページで 音声による回答を提示する. PocketMMDAgent 上に $2 つ$ のボタンを設置し (図 3), 左のボタンには質問応答ペー ジへのジャンプ機能を, 右のボタンにはシナリオ再開機 能を持たせる．学習者に対しそれらの機能や使い方につ いて, 質問応答を行う際に教師エージェントに説明発話 をさせる，要素 (5) では，各章に対して静的に指定した 次章を続けて再生するか終了するかを学習者に選択させ る. 音声対話コンテンツのシナリオは状態遷移を制御す る FST コマンドで記述された FST ファイルで定められ， 本システムでは次章の再生を学習者が選択した場合, 指 定した FST ファイルを FST コマンドによりロード及び再 生する。また，各シナリオ構成要素において発話者を明 確にするために発話用モーションを発話時に起こし，被 発話者を明確にするために発話者に被発話者の方向を向 かせるように指定した。要素 (6) では学習者に対して提 示するスライド切り替え, 新たなスライドを学習者に提 示する.

これらのチュータリングシステムにおける対話シナリ オは複雑な状態遷移を必要とせず，シナリオを記述した 発話者, 発話内容, フラグ, ファイル名から形式立てた テキストから容易に FST ファイルに変換することができ る. 例えば，表 1 のようなシナリオテキストでは LECで 要素 (1) のフラグを指定, teach で発話者に教師エージェ ントを指定，“””以降を発話内容として，表 2 のような FST ファイルの内容に変換する。 また, SLIDE で要素 (6) のフラグを指定，表示させたいスライドのパスを与える ことで、チュータリングの画面のスライドを切り替える ことができる. 


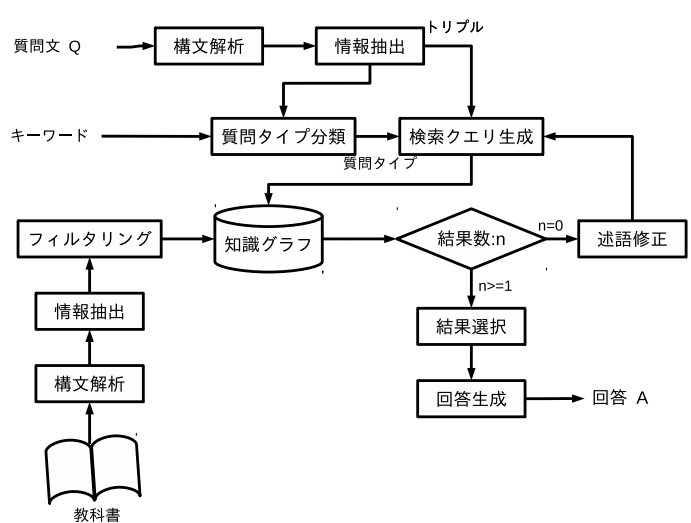

図 5 回答生成システムの構成図

\section{4. 質問応答機能}

本チュータリングシステムでは, 多様な学習者へ対応 するために質問応答機能を付加する。一般にチュータリ ングタスクでは回答生成のための大規模な質問応答対の 入手並びに作成が困難である，そこで本研究では，回答 生成のための構築コストの低い知識要素として, 教科書 の本文から知識グラフを生成し，それへの問い合わせを 用いた回答の生成を行う (図 5). 知識グラフを用いた質 問応答により，質問応答ペアのデータセットを用意しづ らい科目でも学習者の質問への回答が可能になると考え られる。

知識グラフは，知識に関する事象及び関係性などを表 す概念であり, 関係情報同士をあらかじめリンクで結び 高速にアクセスすることができ, エンティティ間の構造 化された関係情報を提供するため, 質問応答に役立つこ とが知られている [Bordes 14]. 知識グラフの表現手段で ある RDF は主語, 述語, 目的語の 3 要素をトリプルと みなして関係情報を有向ラベル付きグラフとして表現し， SPARQL などのクエリ言語により関係情報を問い合わせ ることができる。

\section{$4 \cdot 1$ 知識グラフの構築}

本研究は問い合わせに使用する知識グラフは, 人手で 作成した機械学習に関するオントロジーに対し, 教科書 の本文から単語間の関係性を抽出し生成した Resource Description Framework (RDF) で補完したものを用いる. オントロジーは機械学習の問題を階層化した機械学習 クラス, 個別のアルゴリズムクラス, 学習手法クラス, モ デルクラス, パラメータクラス, データの種類クラス (数 值・カテゴリカル・混合) を設定する. 機械学習クラスの 属性としてアルゴリズムクラス, 学習手法クラス, デー タの種類クラスを, アルゴリズムクラスの属性にはモデ ルクラスとパラメータクラスを持たせる.

知識グラフは, 教科書の文章を構文解析し項構造と並
列構造からトリプル候補を抽出し RDF 形式で生成する. 解析結果で得られる項構造のみでは, 並列関係にある名 詞は 1 つしか得られない場合があるため, 並列構造にも 着目する必要がある.トリプル候補を抽出するために, 京 都大学黒橋・河原研究室で開発された形態素解析システ ム Juman++ [Morita 15], 日本語構文・格・照応解析シス テム KNP [Kawahara 06] を用いる.

KNPによって得られる特徵のうち, 述語項構造の抽出 を行う. 述語項構造は基本句の特徴として出力されるも のであり，文中の述語とそれに係る単語やその格情報を 得ることができる. 本研究ではガ格を主語, 述語を関係, その他の格を目的語とみなし, トリプル候補として抽出 した。 また，KNPによって得られる特徵のうち，並キ， 並列類似度, 並結文節数, 並結句数, 複合 $を$ 用いて並 列関係にある名詞を抽出する．並列構造と判別した名詞 は多重集合 (rdf:Bag) として記述する.

得られたトリプル中には形式名詞などの表現内容の薄 い，それ単体であまり意味をもたない語を含んだトリプ ルとそれらを含まないものが混在している. 木村ら [木村 17] の研究では単文型の知識構築の際, 意味の薄い文が生 成されたことによる回答生成精度の低下が見られた。本 研究では, 意味の薄いトリプルが問い合わせの際ヒット して回答生成のノイズとなることを軽減するために，卜 リプルに対して式 (1) に基づいて算出した TF-IDF 值に よるフィルタリングを行う．算出のための文書として教 科書テキストを節単位で分割した分かち書きを用いた。

$$
\begin{aligned}
t f i d f_{i, j} & =t f_{i, j} i d f_{i} \\
& =\frac{n_{i, j}}{\sum_{k} n_{k, j}} \cdot \log \frac{|D|}{\left|\left\{d: d \ni t_{i}\right\}\right|}
\end{aligned}
$$

$n_{i, j}$ : 文書 $d_{j}$ における単語 $t_{i}$ の出現回数

$\sum_{k} n_{k, j}$ : 文書 $d_{j}$ における全ての単語の出現回数 の和

$|D|$ : 総文書数

$\left|\left\{d: d \ni t_{i}\right\}\right|$ : 単語 $t_{i}$ を含む文書数

以上の方法により抽出されたトリプルを Notation3 (N3) 形式で SPARQL サーバに格納する.

\section{$4 \cdot 2$ 回答 生 成}

回答生成では, 質問文の構文解析からトリプルを作成 し，空な要素を知識グラフに問い合わせ，テンプレート ベースで回答生成を行う. 回答生成システムの構成は図 5 のとおりである.

まず，質問文から知識グラフへ問い合わせるためのキー ワードを抽出して，知識グラフでのトリプル抽出と同様 の処理で質問内容語を抽出する．次に，質問意図に合わせ た形式の回答を生成するために，機械学習分野において 尋ねられることの少ないと考えられる who 以外の $4 \mathrm{~W} 1 \mathrm{H}$ (why, when, where, what, how) をターゲットとして，質 問文のタイプ分類を行う. 今回は大規模な質問応答対など 
の学習データの入手が困難なため, 類似度ベースによる分 類を用いた. Fukumoto ら [Fukumoto 07] は，質問文の表 層に質問意図に関わる単語が現れることを示しており，そ れを参考に Wikipedia で学習させた Word2Vec [Mikolov 13]・Doc2Vec [Le 14] を用いて設定するキーワードと 質問文の情報との類似度により分類する．Word2 Vec で は，疑問詞と「何故，いつ，どこ，何，どう」に対して， Doc2Vecでは，質問文と「理由，時，場面，意味，方法」 に対して類似度を計算する．正規化後のスコアに対して， 疑問詞が what 型以外ならば前者に，そうでなければ後 者にバイアスをかけて加算しスコア最大值の型を質問タ イプと判定する.

RDF 形式の知識グラフは SPARQL クエリによって問 い合わせることができる，本研究では， SPARQL クエリ を質問内容語を用いてテンプレートベースで生成し，知 識グラフへの問い合わせを行う。その際，問い合わせ結 果数が 0 件ならば, 質問文から得られたトリプルの述語 を，Word2Vecによる類似度計算から類似度が最も高い とされた知識グラフ内の述語と置き換えて再度問い合わ せを行う。また問い合わせ結果数が複数ならば，得られ た結果からランダムに 1 件選択する.

そして，知識グラフの問い合わせ結果を基に，「[主語] は [目的語]を[述語][質問タイプ別表現]である」をテン プレートとして回答文を生成する．質問タイプ別表現は （1）から (why)，(2) とき (when)，(3) 場面 (where)，(4) None (what)，(5) 方法 (how) と設定し，質問意図に合わ せた回答形式をとる．例えば，質問意図が how であると 判断された場合には，回答は「〜する方法である」とい う文末で生成される。述語はJuman++により得られる品 詞ごとに変形させてテンプレートに適用させる.

このとき，知識グラフへの問い合わせにより回答に必 要な情報が得られなかった場合は,「すみません。わかり ません。」という定形での回答を生成する，この生成され た回答文を音声として学習者に提示するために，本シス テムでは Open JTalk[大浦 10] と教師エージェントの音響 モデルを用いて回答音声となる wav ファイルを生成し， そのファイルパスを返し，ブラウザ上で再生させる.

\section{5. 動 作 検 証}

本研究で提案した三者対話チュータリングシステムの 動作を検証するために，全サーバを公開サーバとしたと きの動作，知識グラフを用いた回答生成の動作の検証を 行う。対話コンテンツ用データサーバ，質問応答用 web サーバとして Apache ${ }^{* 2}$ を，回答生成を行うための API サーバには Web アプリケーションフレームワークである Flask *3 を，問い合わせるための SPARQL サーバには，

*2 Apache: https://httpd.apache.org/

*3 Flask: http://flask.pocoo.org/
Apache Jena Fuseki *4 を用いた.

\section{$5 \cdot 1$ テストデータ}

知識グラフの作成には, 機械学習の教科書 [荒木 18] の 1, 3, 4, 5 章から数式・図に関する文章を除いた 466 文を 用い，回答生成には，テストデータとして自作した質問 文 7 件を用いた。これらの質問文は目的として，(1) 主 語を問う，(2) 目的語を問う，(3) 述語を問う，(4) 質問夕 イプ, (5) 述語の再検索を設定し作成した.

\section{$5 \cdot 2$ 検 証 結 果}

本チュータリングシステムは, 前述のツールを利用し て図 4 の全サーバを公開サーバ上に置いた状態で対話シ ナリオや質問応答機能が動作することが確認できた。

知識グラフの生成において, 教科書の文章から 401 件 が取得できている，回答生成において，テストデータと して作成した質問文と生成された回答を表 3 に示す。質 問を入力することにより, 主語, 述語, 目的語に質問タ イプ別表現を加えた回答が得られたが，whyを問うた質 問のように回答の構造関係の一部を含まない質問では, 正しい回答を返すことができないことが確認できた。ま た，知識グラフへの問い合わせにおいて，検索できない クエリであった場合はわからないという旨の回答を返し ている.

\section{$5 \cdot 3$ 考察}

動作検証により，全サーバを公開サーバとして動作さ せることが可能であることが確認できた。さらに，ログ の収集が可能であるため今後学習者の学習履歴として, 学習者の状態把握に利用することができ, 本チュータリ ングシステムは有用なシステム構成であると考えられる。 主要機能を公開サーバで実現することにより，ユーザは PocketMMDAgent と web ブラウザを使用できればチュー タリングを受けることが可能であるといえ，パソコンだ けでなくスマートフォンやタブレットのようなデバイス からでもチュータリングを受けることが可能となる.

また，教科書から 1 文につき約 1 トリプルで知識グラ フとして表せているため, 教科書から抽出した項構造か ら知識グラフを生成することは有効であると考えられる. 知識グラフの生成過程において, TF-IDF によるフィル タリングによって 550 件のトリプル候補が削除されてお り，削除されたトリプル候補にはこと，もの，ためなど 意味の薄いものが含まれているものが多く効果的に作用 していると考えられる.

知識グラフを用いて生成された回答は, 主語, 述語, 目 的の 3 単語が主となっており，これだけの情報ではチュー タリングという場面においては学習者への回答としては

\footnotetext{
*4 Apache Jena Fuseki: https://jena.apache.org/ documentation/fuseki2/
} 
表 3 回答生成結果例

\begin{tabular}{|c|l|c|c|l|}
\hline 目的 & 質問 & 正解タイプ & 判定タイプ & 回答 \\
\hline \hline 主語を問う & 何がクラスを分離しますか & what & what & 境界面はクラスを分離する \\
\hline 目的を問う & $\begin{array}{l}\text { 教師なし学習は何を学習するん } \\
\text { ですか }\end{array}$ & what & what & $\begin{array}{l}\text { 教師なし学習は規則性を学習す } \\
\text { る }\end{array}$ \\
\hline 述語を問う & $\begin{array}{l}\text { モデル推定はパラメータをどう } \\
\text { するんですか }\end{array}$ & how & how & $\begin{array}{l}\text { モデル推定はパラメータを推定 } \\
\text { する方法です }\end{array}$ \\
\hline why を問う & 木が分類できる理由は何ですか & why & how & すみません。わかりません \\
\hline where を問う & $\begin{array}{l}\text { 識別問題は何を探す場面の問題 } \\
\text { ですか }\end{array}$ & where & where & $\begin{array}{l}\text { 識別問題は境界面を探す場面で } \\
\text { す }\end{array}$ \\
\hline how を問う & $\begin{array}{l}\text { ぞうやって規則を発見しますか } \\
\text { how }\end{array}$ & $\begin{array}{l}\text { パターンマイニングは規則を発 } \\
\text { 見する方法です }\end{array}$ \\
\hline 述語再検索 & $\begin{array}{l}\text { パターンマイニングは何を見つ } \\
\text { けますか }\end{array}$ & what & what & $\begin{array}{l}\text { パターンマイニングは規則を発 } \\
\text { 見する }\end{array}$ \\
\hline
\end{tabular}

不十分であると考えられる Aghaebrahimian ら [Aghaebrahimian 16] は, 知識グラフを用いた質問応答において SimpleQuestions データセット [Bordes 15] を用いた実験 を行い，エンティティ認識やシステム全体の精度による 評価をした．提案システムでは，回答できる質問構造に よる制約などにより十分なテストセットを作成すること は難しく，このような評価は難しい，提案システムのよ うな質問応答タスクでは, 評価指標として回答の満足度 などが考えられるが，前述のとおり不十分な情報の回答 であり現状での回答生成機能をこの指標で評価すること は難しい. 今後, 教科書中の文や節単位の情報も利用し, より情報を十分に持たせた回答を生成した上での評価が 課題として挙げられる. 知識グラフの範囲内の質問に対 して簡易的な回答を生成することに関しては，教科書か ら生成した知識グラフで可能であることが表 3 からわか り，教科書のテキストの解析を用いることにより質問応 答機能を低コストで開発することは可能であると考えら れる。

また，現状ではあるトリプルの内容が別のどのトリプ ルに起因しているのかという情報はとれていないため, why や where などの質問タイプに対する回答を行うため に質問文に回答の構造が含まれていなければ検索できず 生成することができない，そのため，知識グラフにおい て文間や文節間の関係を用いるなどの検討が必要である. 問い合わせ結果が複数得られた場合, 現在はランダムに 1 つ選んでいるが, 回答としての妥当性を何らかの基準 で評価する方法を組み込むことが必要である.

また，チュータリングシステムでは多様な知識レベル のユーザへの対応をする必要がある．現在は質問応答機 能によって対応しているが，三者対話システムでは質問 対象者を切り替えることで生徒エージェントへの質問と 学習者への質問の割合を変化させることができ，それら をユーザによって変化させることでも対応可能であると 考えられる。

\section{6. 評 価 実 験}

本研究でチュータリングシステムに用いた三者対話形 式について，学習者の心理的負担を軽減できるか検証す るために, 本実験では二者対話形式と三者対話形式を比 較するアンケート調査をし評価を行う.

\section{$6 \cdot 1$ アンケート方法}

著者所属組織のオープンキャンパスで研究室見学に参 加した高校生 85 名に対し，アンケートを実施した。本 チュータリングシステムは機械学習の初学者を対象とし ていることから、理系大学志望の, 高校生は本システム の想定ユーザに近いと考えられる.

アンケートは，二者対話形式と三者対話形式でのそれ ぞれ 111 秒間のチュータリングデモ映像を見せた後に行っ た。デモ映像ではどちらも初歩的な内容である“機械学 習の分類”についての講義を行い，ユーザ発話については 画面下部に字幕として映像に加えたものを用意した。シ ナリオの解説部分は同一であるが対話形式による差を確 認するために，二者対話形式での教師エージェントから ユーザへの質疑を，三者対話形式ではエージェント間で の質疑に一部変更している. 実験の教示として，デモ映 像の画面下部にユーザ発話が字幕として表示されること を伝え，講義を受けるユーザが自分自身のみだけである ことを想定して視聴することを指示した。

アンケートの設問は，以下のとおりである.

Q1 どちらのシステムを学習用として使いたいですか

Q2 どちらのシステムがリラックスして利用しやすいと 感じますか

Q3 どちらのシステムが質問しやすいと感じますか 各設問に対して 5 段階で尺度を設け，二者対話形式と三 者対話形式どちらがよいか，アンケートを記入させた．

アンケートにおいて両対話形式の公平性を保つために, 本実験ではオープンキャンパスの実施日によりデモ映像 
の再生順を変更し, 1 日目 (二者対話, 三者対話の順) は 47 名, 2 日目 (三者対話, 二者対話の順) は 38 名にアン ケートを実施した。また，評価実験の前に行った研究紹介 においても公平性を考慮し，教科書のデータからチュー タリングシステムの開発を行っているという説明にとど め，心理的負担についての言及を避けた.

\section{$6 \cdot 2$ 評 価 結 果}

それぞれの設問の回答をまとめると図 6 のようになる. この結果をもとに，二者対話形式がよい・どちらともい えない・三者対話形式がよいという 3 カテゴリとみなし て, 帰無仮説を「回答される項目の度数に偏りがない」 とし，適合度の $\chi^{2}$ 検定を行った。検定の結果は表 4 の とおりになり，どの設問においても有意差が認められた。

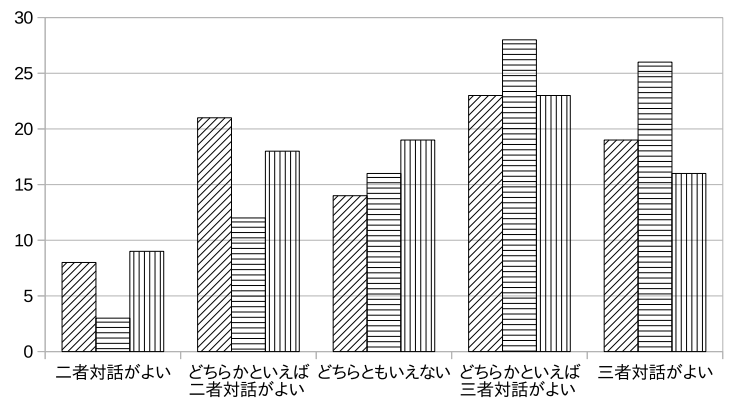

図 6 アンケート結果

表 $4 \chi^{2}$ 検定結果

\begin{tabular}{|c|c|c|c|}
\hline 設問 & 項目 & 回答数 & $\chi^{2}(2)$ \\
\hline \hline \multirow{4}{*}{ Q1 } & 二者対話がよい & 29 & \\
& どちらともいえない & 14 & $13.86^{* *}$ \\
& 三者対話がよい & 42 & \\
\hline \multirow{4}{*}{ Q2 } & 二者対話がよい & 15 & \\
& どちらともいえない & 16 & $34.90^{* *}$ \\
& 三者対話がよい & 54 & \\
\hline \multirow{4}{*}{ Q3 } & 二者対話がよい & 27 & \\
& どちらともいえない & 19 & $7.15^{*}$ \\
& 三者対話がよい & 39 & \\
\hline
\end{tabular}

※) **: $\mathrm{p}<0.01, *: \mathrm{p}<0.05$

さらに，各項目間の差を比較するため帰無仮説を「各 項目間で度数に偏りはない」とし, 有意水準 $\alpha=0.05$ と したときのライアンの名義水準を用いた多重比較を行っ た．結果は，表 5 , 表 6 , 表 7 のとおりである。“二者対話 がよい”を“D”，“どちらともいえない”を“N”，“三者対 話がよい”“T”として表す。

\section{$6 \cdot 3$ 三者対話形式による効果}

$\chi^{2}$ 検定において，すべての設問で帰無仮説は棄却され 有意な差がみられ，さらにQ2での多重比較において，“
表 $5 \mathrm{Q} 1$ の各項目に対するライアンの名義水準を用いた 多重比較結果

\begin{tabular}{cccc}
\hline 比較 & 臨界比 & $\mathrm{p}$ & 名義水準 \\
\hline $\mathrm{D}>\mathrm{N}$ & $2.13 *$ & 0.0324 & 0.03333 \\
$\mathrm{D}=\mathrm{T}$ & 1.42 & $>0.05$ & 0.03333 \\
$\mathrm{~N}<\mathrm{T}$ & $3.61 *$ & 0.0004 & 0.01667 \\
\hline
\end{tabular}

表 6 Q2 の各項目に対するライアンの名義水準を用いた 多重比較結果

\begin{tabular}{cccc}
\hline 比較 & 臨界比 & $\mathrm{p}$ & 名義水準 \\
\hline $\mathrm{D}=\mathrm{N}$ & 0.00 & $>0.05$ & 0.03333 \\
$\mathrm{D}<\mathrm{T}$ & $4.57^{*}$ & $<0.0002$ & 0.01667 \\
$\mathrm{~N}<\mathrm{T}$ & $4.42^{*}$ & $<0.0002$ & 0.03333 \\
\hline
\end{tabular}

表 7 Q3 の各項目に対するライアンの名義水準を用いた 多重比較結果

\begin{tabular}{cccc}
\hline 比較 & 臨界比 & $\mathrm{p}$ & 名義水準 \\
\hline $\mathrm{D}=\mathrm{N}$ & 1.03 & $>0.05$ & 0.03333 \\
$\mathrm{D}=\mathrm{T}$ & 1.35 & $>0.05$ & 0.03333 \\
$\mathrm{~N}<\mathrm{T}$ & $2.49^{*}$ & 0.0124 & 0.01667 \\
\hline
\end{tabular}

三者対話がよい”という回答は“二者対話がよい”という 回答より有意に多いことがわかる.リラックスできるシ ステムでは，ユーザの心理的負担を軽減することができ ると考えられるため, 本研究のチュータリングシステム において三者対話形式を採用することは妥当性があると 考えられる。

しかし，使いたいかどうかや質問しやすいかという観 点では， $\chi^{2}$ 検定で有意差が表れた一方で，多重比較に よっては二者対話形式と三者対話形式の間に有意な差は 確認されなかった。また，アンケート結果から Q1 の回答 と Q2 の回答とが一致しない回答者もみられたため，運 用の際はより利用したいと思わせる工夫が更に必要であ ると考えられる。

\section{7.お りりに}

ある科目の習得を独学で行うのは，特に初学者におい て自力で疑問解決にあたるのが困難である場合がある。そ こで，学習支援として質問に対する回答を自動的に返す 対話型チュータリングシステムが有用であると考え, 本 研究では，対話を成り立たせる機能として知識グラフに よる質問応答機能を用いた三者対話チュータリングシス テムを PocketMMDAgent を用いて開発した。動作検証 により公開サーバ上で提案システムが動作し, 質問応答 において一定の構造をもつ質問発話に対して回答を音声 により提示できることが確認された。本システムを用い た学習の効果については，長期的な使用状況をモニター する必要であるため，今後の課題とする。 
謝

\section{辞}

本研究を行うにあたり, PocketMMDAgent の使用法に つきご指導頂いた名古屋工業大学大学院 李 晃伸教授, 資 金提供頂いた TIS 株式会社に深謝する。本研究は JSPS 科研費 $18 \mathrm{~K} 11569$ の助成を受けたものである.

\section{$\diamond$ 参 考 文 献 $\diamond$}

[Aghaebrahimian 16] Aghaebrahimian, A. and Jurčíček, F.: Opendomain factoid question answering via knowledge graph search, in Proceedings of the Workshop on Human-Computer Question Answering, pp. 22-28 (2016)

[荒木 18] 荒木雅弘：フリーソフトではじめる機械学習入門 (第 2 版), 森北出版 (2018)

[有本 18] 有本庸浩, 飯尾尊優, 吉川雄一郎, 石黒浩 : 実環境で人に 高度な対話感を与える複数体型対話ロボットシステムの開発, 電 子情報通信学会論文誌, Vol. J101-D, No. 1, pp. 79-91 (2018)

[Bordes 14] Bordes, A., Chopra, S., and Weston, J.: Question answering with subgraph embeddings, in Proceedings of the 2014 Conference on Empirical Methods in Natural Language Processing (EMNLP), Doha, Qatar (2014)

[Bordes 15] Bordes, A., Usunier, N., Chopra, S., and Weston, J.: Large-scale simple question answering with memory networks, arXiv preprint arXiv:1506.02075 (2015)

[Fukumoto 07] Fukumoto, J.: Question answering system for nonfactoid type questions and automatic evaluation based on BE method, in NTCIR, pp. 441-447 (2007)

[Graesser 17] Graesser, A., Forsyth, C., and Lehman, B.: Two heads may be better than one: Learning from computer agents in conversational trialogues, Teachers College Record, Vol. 119, No. 030302 (2017)

[Kawahara 06] Kawahara, D. and Kurohashi, S.: A fully-lexicalized probabilistic model for japanese syntactic and case structure analysis, in Proceedings of the Main Conference on Human Language Technology Conference of the North American Chapter of the Association of Computational Linguistics, HLT-NAACL '06, pp. 176-183 (2006)

[Kertkeidkachorn 18] Kertkeidkachorn, N. and Ichise, R.: An automatic knowledge graph creation framework from natural language text, IEICE transactions on Information and Systems, Vol. 101, No. 1, pp. 90-98 (2018)

[木村 17] 木村輔, 田村諒, 宮森恒 : 要約条件と単文型知識源に基 づく non-factoid 型質問応答手法, DEIM Forum, pp. B8-3-B8-3 (2017)

[久保田 02] 久保田 秀和, 山下 耕二, 福原 知宏, 西田 豊明: POC caster:インターネットコミュニティのための会話表現を用いた 情報提供エージェント, 人工知能学会論文誌, Vol. 17, No. 3, pp. 313-321 (2002)

[Le 14] Le, Q. and Mikolov, T.: Distributed representations of sentences and documents, in International Conference on Machine Learning, pp. 1188-1196 (2014)

[李 11] 李 晃伸, 大浦圭一郎, 徳田恵一 : 魅力ある音声インタラク ションシステムを構築するためのオープンソースツールキット MMDAgent, 電子情報通信学会技術研究報告. NLC, 言語理解と コミュニケーション, Vol. 111, No. 364, pp. 159-164 (2011)

[Luan 18] Luan, Y., He, L., Ostendorf, M., and Hajishirzi, H.: Multitask identification of entities, relations, and coreference for scientific knowledge graph construction, arXiv preprint arXiv:1808.09602 (2018)

[Mikolov 13] Mikolov, T., Chen, K., Corrado, G., and Dean, J.: Efficient estimation of word representations in vector space, arXiv preprint arXiv:1301.3781 (2013)

[Morita 15] Morita, H., Kawahara, D., and Kurohashi, S.: Morphological analysis for unsegmented languages using recurrent neural network language model, in Proceedings of the 2015 Conference on Empirical Methods in Natural Language Processing, pp. 2292-2297 (2015)

[大浦 10] 大浦 圭一郎, 酒向慎司, 徳田恵一：日本語テキスト音 声合成システム Open JTalk, 2010 年度日本音響学会春季講論集,
Vol. 1, No. 2-7-6, pp. 343-344 (2010)

[Sakamoto 09] Sakamoto, D., Hayashi, K., Kanda, T., Shiomi, M., Koizumi, S., Ishiguro, H., Ogasawara, T., and Hagita, N.: Humanoid robots as a broadcasting communication medium in open public spaces, International Journal of Social Robotics, Vol. 1, No. 2, pp. 157-169 (2009)

[杉山 17] 杉山 弘晃, 目黒 豊美, 吉川 雄一郎, 大和 淳司 : 複数口 ボット間連携による対話破綻回避効果の分析, 2017 年度人工知能 学会全国大会論文集 (第 31 回), Vol. JSAI2017, pp. 1B2OS25b21B2OS25b2 (2017)

[杉山 18] 杉山 弘晃, 水上 雅博, 成松 宏美 : 複数ロボット協調に よる一問一答型雑談対話からの脱却, 2018 年度人工知能学会全 国大会論文集 (第 32 回), Vol. JSAI2018, pp. 3J204-3J204 (2018)

[Swartout 10] Swartout, W., David, T., Ron, A., Dan, N., Paul, D., Kerry, B., Josh, W., Anton, L., Shrikanth, S. N., Diane, P., Chad, L., Jacquelyn, M., Priti, A., Matt, L., Jen-Yuan, C., Jillian, G., Selina, C., and Kyle, W.: Ada and Grace: Toward Realistic and Engaging Virtual Museum Guides, in Proceedings of the 10th International Conference on Intelligent Virtual Agents (IVA), pp. 286-300 (2010)

[Yoshikawa 17] Yoshikawa, Y., Iio, T., Arimoto, T., Sugiyama, H., and Ishiguro, H.: Proactive conversation between multiple robots to improve the sense of human-robot conversation, in 2017 AAAI Fall Symposium Series (2017)

〔担当委員 : 松山 洋一]

2019 年 5 月 19 日 受理

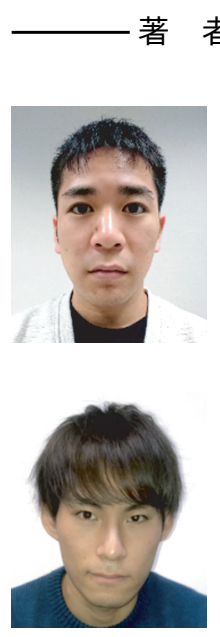

\section{者 紹 介}

\section{小嶋 拓海}

2019 年京都工芸繊維大学工芸科学部情報工学課程卒業. 現 在同大学院工芸科学研究科情報工学専攻博士前期課程在 学中.

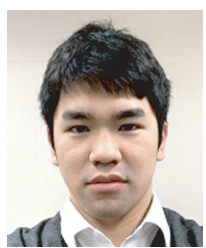

飯田 㧓矢

京都工芸繊維大学 工芸科学部情報工学課程在学中.

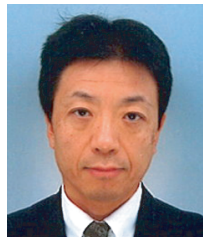

荒木 雅弘 (正会員)

1993 年京都大学大学院工学研究科情報工学専攻博士後期 課程研究指導認定退学. 同年, 京都大学工学部助手. 1997 年同大学総合情報メディアセンター講師. 1998 年博士 (工 学, 京都大学) 取得. 1999 年京都工芸繊維大学工芸学部助 教授. 2007 年同大学院工芸科学研究科准教授. 現在に至る. 